\title{
SKIPPERS AND BUTTERFLIES OF A DISJUNCT ASPEN PARKLAND AREA IN ALBERTA
}

NORBERT G. KONDLA, Parks Division, Alberta Recreation and Parks, Rimbey, Alberta TOC $2 \mathrm{JO}$.

Accounts of butterfly faunas and habitat use of the Alberta aspen parkland are scarce. Case and Bird provide some information on the Peace River parkland 5 and Thormin deals with the Beaverhill Lake area. ${ }^{24}$ However, other accounts treat individual species (e.g. Bird ${ }^{3}$ ) or taxonomic matters (e.g. Ehrlich ${ }^{\circ}$ ) rather than the typical fauna of a given habitat. This paper reports on the most detailed study of a local aspen parkland butterfly fauna undertaken to date in Alberta.

The central aspen parkland section is a fairly distinctive zone in southcentral Alberta. Two outliers of aspen parkland are present near Drumheller, on the Winterlng Hills and on the Hand Hills. The Wintering Hills, an upland rising more than $120 \mathrm{~m}$ above the plains southwest of Drumheller, are a generally east-west oriented ridge, the northeastern escarpment of which supports a substantial area of aspen parkland whlch is separated by a distance of about 80 $\mathrm{km}$ from the central aspen parkland.

For this study, we selected a representative area of about 260 ha for collection and observation of butterflies. All habitats were intensively searched by the writer and S. Harrls from 1976 to 1980 inclusive on 20 different days with a seasonal spread from 1 May to 3 September. Vislts were timed to minimize the possibillty of missing any species because of Its flight period.
The study area was situated in 2826-18-W4, about $11 \mathrm{~km}$ south of East Coulee, on the highest portion of the hills where elevation ranges from 945 $\mathrm{m}$ to $1037 \mathrm{~m}$. Here the escarpment is dissected by ravines, with local relief varying from gently rolling to steeply sloping. Figure 1 shows the general appearance of the study area.

About $50 \%$ of the study area is covered by Aspen Poplar forest with a moderately well-developed low shrub understory of Rose and Buckbrush. The herbaceous component of the forests is rich and includes such species as Sprengel's Sedge, Wild

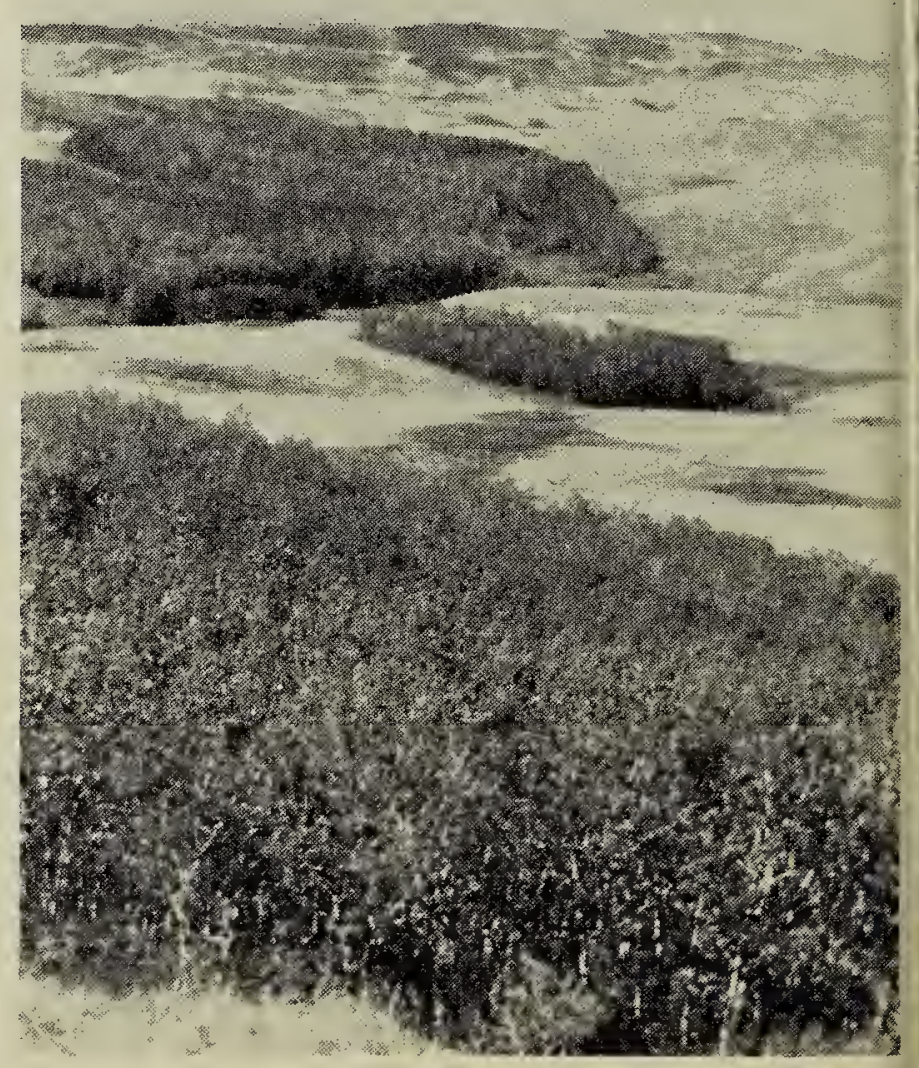

Figure 1. General view of the study area. 
letch, Peavine, Canada Anemone, ind Western Canada Violet.

About $30 \%$ of the study area conists of grassland, most of which was lominated by Rough Fescue prior to he era of intensive cattle grazing. Much of this grassland has been alered to the point where Porcupine arass and June Grass are now lominant. Certain slopes with a south nd west exposure support an open rass-forb vegetation typical of oulees in the region.

The remainder of the study area is ccupied by shrublands and misellaneous local vegetation types. imall stands of Hawthorn, hokecherry, and Saskatoon are resent, as are larger areas of Beaked Willow. Low shrub thickets of Buckbrush, Rose, and Gooseberry re prevalent. Miscellaneous egetation types are Bearberry mats, White birch stand, and two small eepage areas.

The area is floristically interesting, specially from a biogeographic erspective. In a small area one can ind such unlikely associates as leart-leaved Arnica (a mountain pecies), White birch (a boreal forest pecies), and Pincushion Cactus (a rairie-badlands species).

\section{nnotated Llst}

In the following list the term spring efers to May and June while summer efers to July, August and the first few ays of September. Butterfly henology is described with terms ke "early spring to mid-summer." ates indicate days for which pecimen records are available and re written in an abbreviated format e.g. 29-7-78 means 29 July 1978). lost of the common names are from ooper ${ }^{12}$. Scientific names follow dos assos $^{7}$ except where more recent ork indicates that a change is waranted.

\section{Hesperlldae}

TAWNY-EDGED SKIPPER (Polites themistocles) - a worn specimen was found 1-8-77 in low shrub habltat near aspen forest; early to midsummer.

LONG DASH (Polites mystic dacotah) uncommon in grassland; 13-7-79; flight period not known.

UNCAS SKIPPER (Hesperia uncas uncas) - one female was found 29-7-78 on a west-facing hillside in open Porcupine Grass-June Grass vegetatlon; flight period not known.

ASSINIBOIA SKIPPER (Hesperia comma assiniboia) - locally abundant 29-7$78,20-8-79,3-8-80$; mid to late summer; this Insect was easlly observed on flowers of Liatris punctata (Blazing Star) and showed pronounced hilltopping behavior; up to 8 individuals would frequently engage in rapid, erratic flights in tightly spaced groups.

NEVADA SKIPPER (Hesperia nevada) very locally distributed on hilltops and ridge crests with short grass; 23-6-79.

GARITA SKIPPER (Oarisma garita) abundant in grasslands; 19-6-77, 137-79; late spring to mid-summer; more abundant in less heavlly grazed grasslands.

ARCTIC SKIPPER (Carterocephalos palaemon mandan) - occasional in and near aspen forest; 19-6-77; mld to late spring.

COMMON CHECKERED SKIPPER (Pyrgus communis communis) - abundant in grassland and low shrub habltat; 3-9$78,23-6-79,13-7-79$; late spring to iate summer.

DREAMY DUSKY WING (Erynnis icelus) occasional in and near aspen forest; 21-5-78, 23-6-79; mid to late spring.

PERSIUS DUSKY WING (Erynnis persius) - fairly common in grassland near aspen forest; $30-5-76,21-5-78,9-5-$ $80,18-5-80$; early to late spring.

AFRANIUS DUSKY WING (Erynnis afranius) - falrly common In grasslands; 29-7-78, 9-5-80, 11-5-80; flies in two broods, early to mid spring and mid to late summer. 
NORTHERN CLOUDY WING (Thorybes pylades) - uncommon at the edge of aspen forest; $30-5-76,23-6-79$; mid to late spring.

SILVER-SPOTTED SKIPPER (Epargyreus clarus clarus) - occasional in clearings in aspen forest and along edges of forest; 23-5-76; mid to late spring.

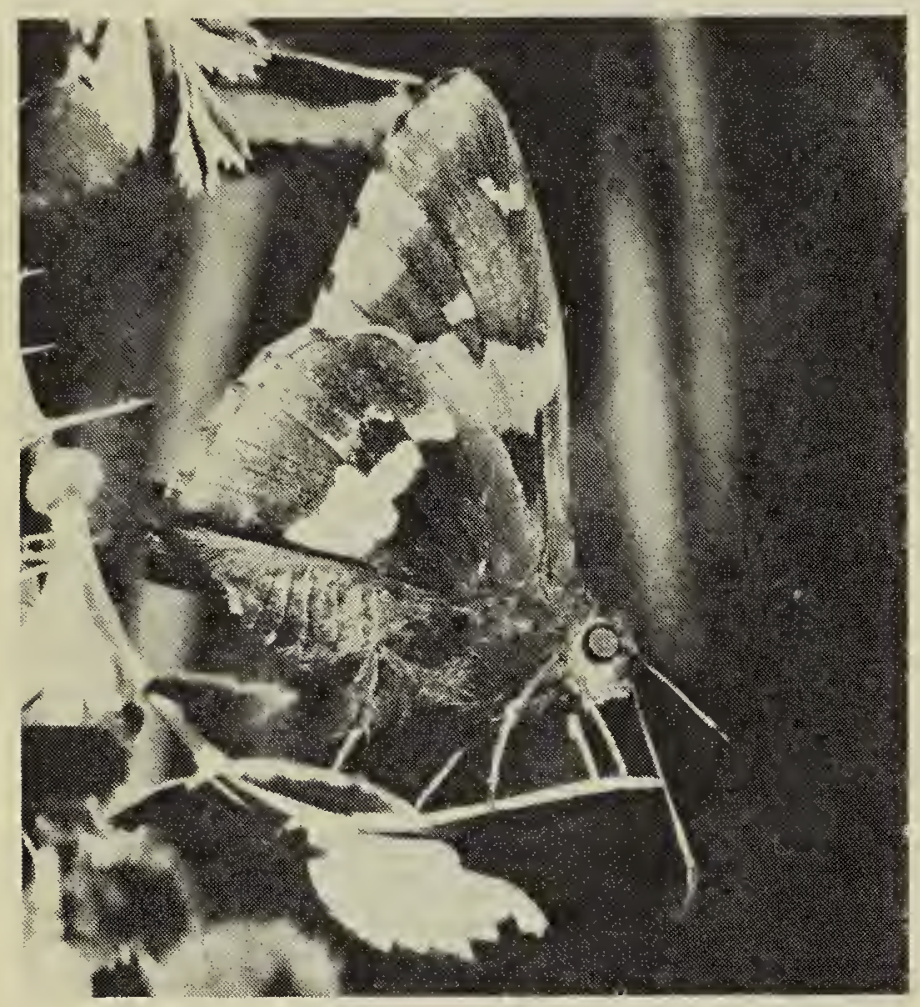

Silver-spotted Skipper.

C. Wallis

\section{Papllionldae}

ZELICAON SWALLOWTAIL (Papilio zelicaon nitra) - Taxonomy follows Fisher ${ }^{11}$; males of the black phenotype were found 8-5-77 and 236-79 on grassland hilltops; males and females of the more abundant yellow phenotype were also found hilltopping 1-5-77, 14-5-78, 29-7-78, 23-6$79,9-5-80,11-5-80$; early spring to mid summer; this lengthy range of dates combined with the fresh condition of the 1978 record suggests either an extremely staggered emergence or a small second brood.

BADLANDS OLD WORLD SWALLOWTAIL (Papilio machaon dodi) - only found on a grassy hllitop; 23-6-79, 20-8-79, 9-5-80, 11-5-80, 18-5-80, 3-8-80. This interesting swallowtall was described in 1939 by J. McDunnough primarlly on the basis of speclmens collected along the Red Deer River. ${ }^{16}$ Hooper use of the name Cypress Hills OI World Swallowtail is misleading. ${ }^{12}$ Th taxon dodi was first descrlbed fror badlands and the greatest portion its range comprises badlands/prairi habitats. Hence the name Badland Old World Swallowtail seems mor appropriate.

CANADIAN TIGER SWALLOWTAI (Papilio glaucus canadensis) abundant in and along edges aspen forest; most frequently see patrolling the edge of the aspen fores at heights of 2 to $5 \mathrm{~m} ; 30-5-76,23-6$ 79; mid to late spring.

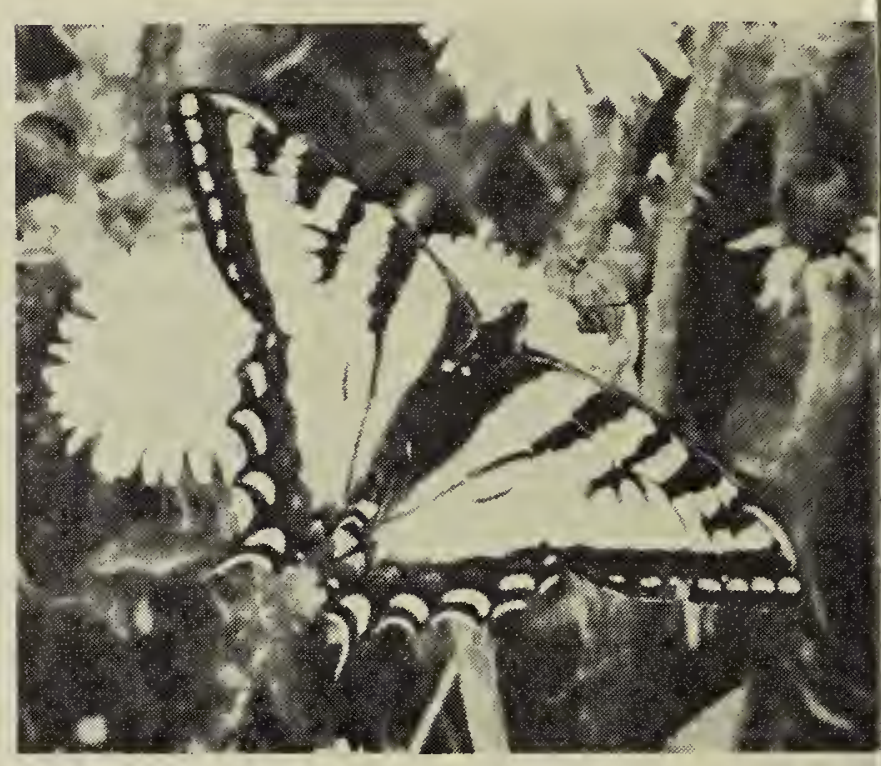

Canadian Tiger Swallowtail.

C. Walli

\section{Plerldae}

WESTERN CHECKERED WHITE (Pieris occidentalis occidentalis) - fairl! abundant in all non-forest areas; fre quently seen hilltopping; the spring brood is dramatically smaller and darker than later broods; 1-5-77, 6-5 $78,3-9-78,23-6-79,20-8-79,4-8-80$ early spring to late summer in multi ple broods.

CABBAGE BUTTERFLY (Pieris rapae) occasional in open areas; 1-5-78, 3-9. $78,2-9-79,9-5-80$; early spring to late summer.

YELLOW ALFALFA BUTTERFLY (Colias philodice eriphyle) - abundant in al non-forested areas; albinistic females were found falrly frequently; 30-5-76 23-5-77, 1-8-77, 16-8-77, 29-7-78, 39-78, 20-8-79, 2-9-79, 18-5-80; early spring to late summer. 
EXANDRA SULPHUR (Colias alexandra alexandra) - fairly abundant in natlve grasslands; 29-7-78, 23-6-79, 20-8$79,18-5-80$; mld spring to late summer.

All females found to date have been albinistic, a situation that appears to be normal for Alberta populations of this taxon. Ferris assigned Alberta prairie material to subspecies astrae ${ }^{10}$ but since then research has shown the presence of pure yellow populations In the prairie region of Alberta. The name used here for these small, yellow prairie Insects Is used provisionally as the most logical available name. In fact there is no published research to show that these populations are the same as the southern C. a. alexandra. Further study may even show that these populations represent a distinct specles. This insect was not reported from the prairies of southern Saskatchewan by Hooper ${ }^{12}$ although it probably occurs there. Here is an opportunlty for naturalists in the prairles of southern Saskatchewan to provlde speclmens for taxonomic and blogeographic study. [There are two known specimens for southern Saskatchewan, both from the Cypress Hills. One was collected several years ago by Donald Hooper, the other in July 1977 by W. Harrls and S. Lamont. - Edltors]

YMPIA MARBLE (Euchloo olympia) only one specimen found on 18-5-80; the most northwesterly reported locality for this specles In North America.

\section{caenidae}

DRAL HAIRSTREAK (Harkenclenus titus immaculosus) - males were found hilltopping on 29-7-78 and 20-8-79; mid to late summer.

DCKY MOUNTAIN STRIPED HAIRSTREAK (Satyrium liparops aliparops) - this is an inconspicuous and apparently uncommon butterfly In Alberta; one female was found 167-77, perched on a Buckbrush leaf at the edge of aspen forest. The subspecies fletcheri, characterlzed by large orange patches on the dorsal forewing, occurs only about $100 \mathrm{~km}$ to the north at Buffalo Lake. When the zone of intergradation between fletcheri and aliparops is documented In this region, It may well be a very narrow zone similar to the situation reported by Clench for two other subspecies of the Strlped Hairstreak In the southeastern USA.

BROWN ELFIN (Callophrys augustinus) very locally dlstributed; found only In a Bearberry patch at the top of the escarpment; 1-5-77, 6-5-78; early to mid spring; insufficlent voucher materlal is available to assign a subspecles name with confidence; geographlc character variation of this specles In Alberta needs to be Investlgated.

GRAY HAIRSTREAK (Strymon melinus) only one speclmen found on 11-5-80.

PURPLISH COPPER (Epidemia helloides) - found at a seepage area on 23-6$79,2-9-79$; late sprlng to late summer.

MELISSA BLUE (Lycaeides melissa melissa) - uncommon In dry grassland; 23-6-79, 2-9-79, 18-5-80, 4-8-80; mid sprlng to late summer.

GREENISH BLUE (Plobojus saepiolus amica) - fairly common in grassland and low shrub areas; 23-5-76, 4-6-77, 18-5-80; mld to late spring.

ACMON BLUE (Plebejus acmon lutzi) very local in dry grassland with bare soil and umbrellaplant (Eriogonum flavum); 23-6-79.

RUSTIC ARCTIC BLUE (Agriades glandon rustica) - locally abundant In dry grassland; fond of nectarling at flowers of Sllverberry (Elaeagnus comutata); 23-6-79, 2-9-79; thls late record plus another from Rumsey In August 1979 suggests a small second brood, apparently an unreported phenomenon.

WESTERN-TAILED BLUE (Everes amyntula albrighti) - falrly common In and near aspen forest; 23-5-76, 30-5-76, 19-6-77; mid to late sprlng.

SILVERY BLUE (Glaucopsyche Iygdamus couperi) - common In grassland and low shrub habltats; 23-5-76, 30-5-76, 1-5-77, 8-5-77, 23-5-77, 4-6-77, 14-5$78,9-5-80,11-5-80,18-5-80$; early to mid spring. 
SPRING AZURE (Celastrina argiolus lucia) - occasional in clearings, edges of forest, and more open portions of the aspen forests; $1-5-77$; early to $\mathrm{mld}$ spring.

\section{Nymphalldae}

WHITE ADMIRAL (Limenitis arthemis rubrofasciata) - occaslonal in aspen forest, clearlngs, and tall shrub thickets; 16-7-77, 13-7-79; late sprlng to mid-summer.

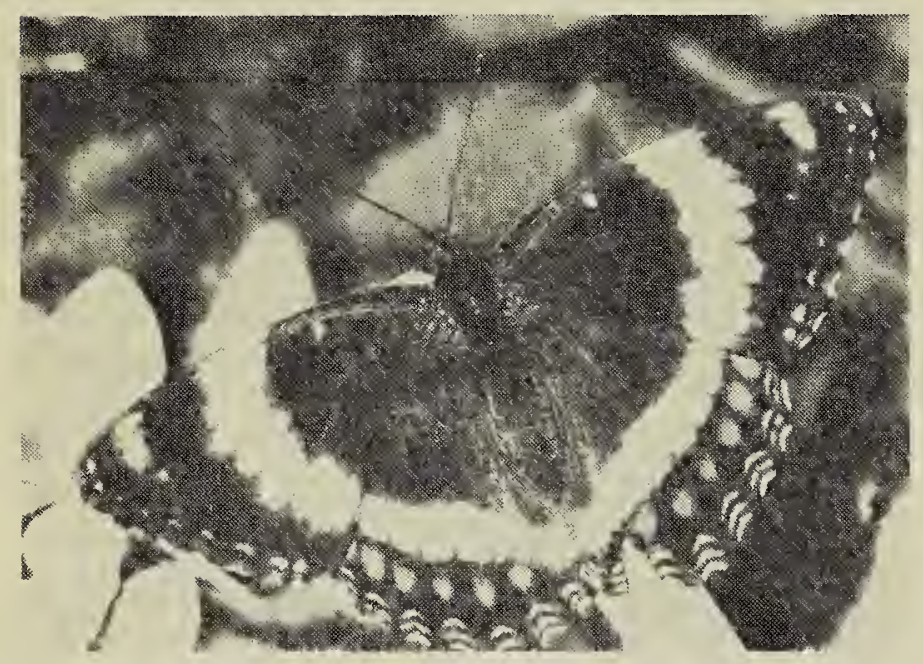

White Admiral.

C. Wallis

RED ADMIRAL (Vanessa atalanta rubria) - occasional in or near forest and tall shrub habitat; 19-6-77; fllght perlod not known.

PAINTED LADY (Cynthia cardui) - occasional in most habltats and sometimes abundant on hilltops; late one afternoon about 50 to 60 males and females were found on a $50 \mathrm{~m}$ by $20 \mathrm{~m}$ section of grassy hilltop; 23-6$79,20-8-79$; only found In 1979, a year in whlch the species was generally abundant in southern Alberta.

MILBERT'S TORTOISE SHELL (Nymphalis milberti furcillata) - occaslonally seen in all habitats; 1-5-77, 19-6-77, 13-5-79; flight period not clear.

MOURNING CLOAK (Nymphalis antiopa antiopa) - occasional in aspen forest and tall shrub habitat; worn, overwintered Individuals were frequently seen In early spring whlle fresh adults were seen from midsummer to late summer; 3-9-78.

SATYR ANGLE WING (Polygonia satyrus) - uncommon In aspen forest; 8-5-77,

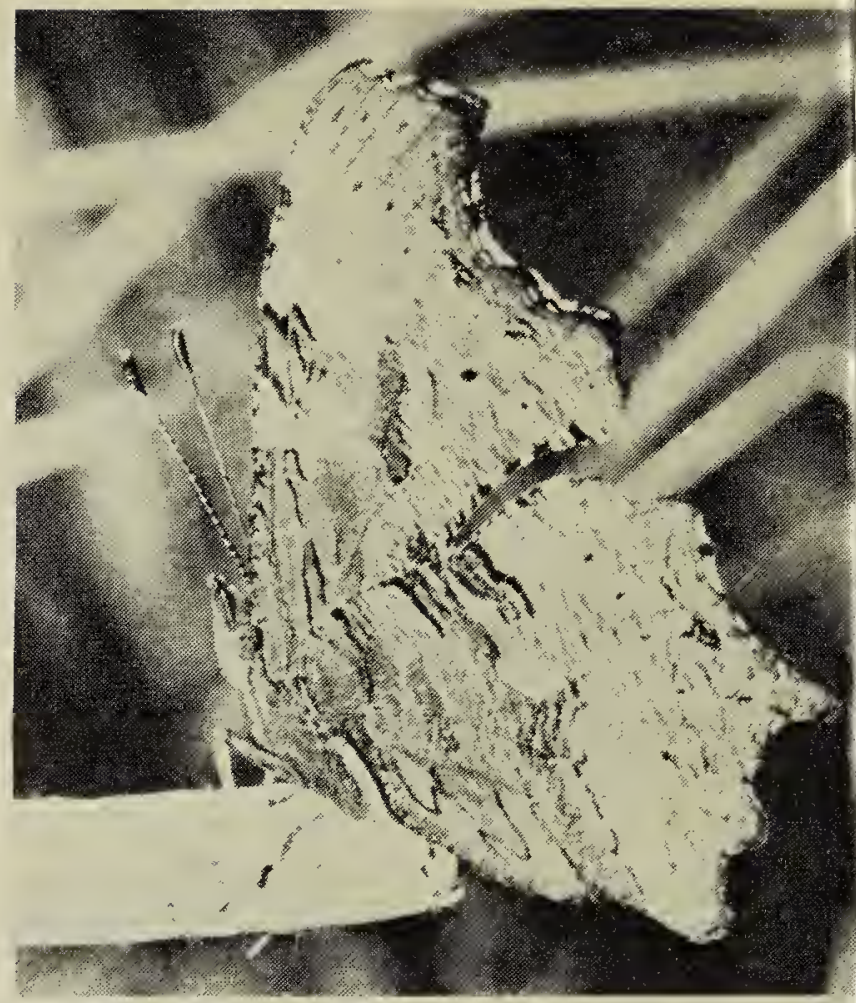

Satyr Angle Wing.

C. Wall

23-5-77, 11-5-80; previous literatu referred Alberta material to the su species satyrus but dos Passos refe Alberta populations to neomarsyas this situation needs further study.

GRAY COMMA (Polygonia progne) found in aspen forest on 13-5-79 ar 3-7-79; the latter record is of the di: tinctive summer form, l-argenteum.

PEARL CRESCENT (Phyciodes tharos) abundant in grassland and low shru areas; mid spring to mid-summer; 18 6-77, 16-7-77, 29-7-78, 18-5-80.

SILVER-BORDERED FRITILLARY (Bolor) selene) - uncommon and local in c near sedge-rlch seepage meadow: 13-7-79.

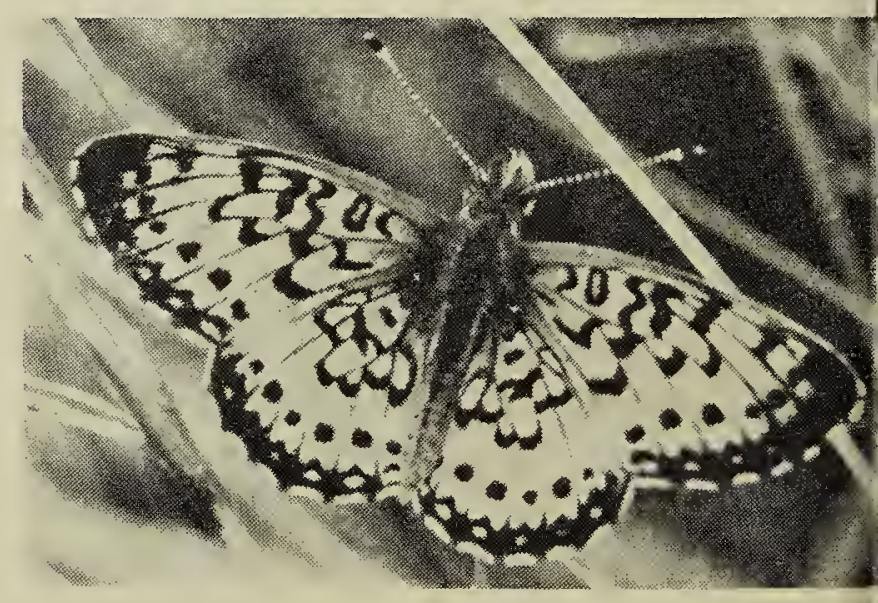

Silver-bordered Fritillary.

C. Walli 
EADOW FRITILLARY (Boloria bellona jenistai) - abundant in rlch grassland and low shrub areas; mid spring to mid-summer, in at least two broods; 23-5-76, 30-5-76, 23-5-77, 4-6-77, 167-77, 21-5-78, 29-7-78, 18-5-80.

DWARD'S FRITILLARY (Speyeria edwardsii) - known only from one fresh male on 30-5-76 at the edge of aspen forest; an exceptionally early record for this uncommon but dlstinctive species.

\section{ALLIPPE FRITILLARY (Speyeria callippe} calgariana) - locally abundant in grassland, especially on hilltops; late spring to mid-summer; 19-6-77, 29-778, 23-6-79, 13-7-79.

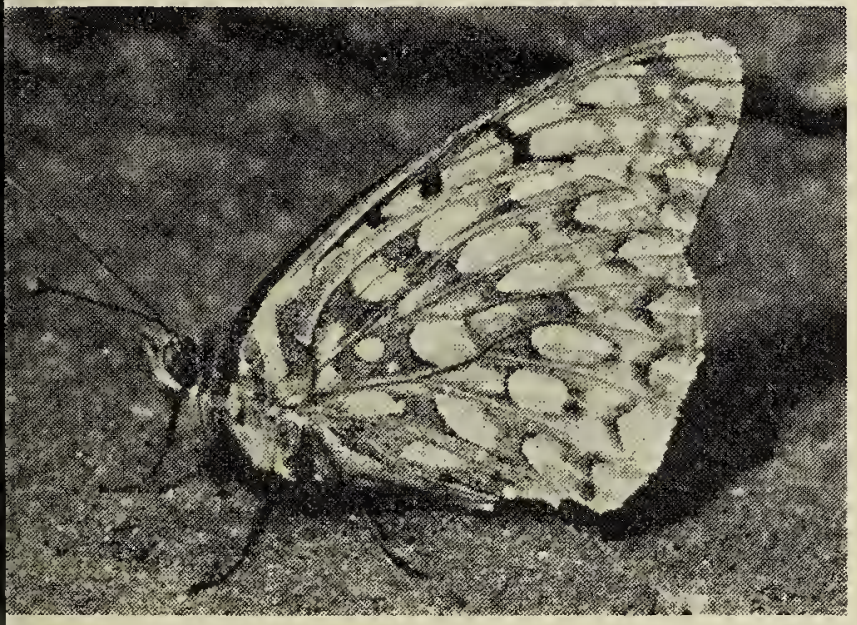

lippe Fritillary.

C. Wallis

LANTIS FRITILLARY (Speyeria atlantis) - very abundant in open habitats; late spring to mid-summer; 19-6-77, 16-7-77, 13-7-79; although typically variable, this population is predominantly of the darker beani phenotype rather than the paler helena phenotype.

ORMONIA FRITILLARY (Speyeria mormonia eurynome) - abundant In most open areas; late spring to midsummer; 16-7-77, 29-7-78.

REAT SPANGLED FRITILLARY (Speyeria cybele pseudocarpenteri) - very abundant, especially at the edges of aspen forest; females were frequently noted well withln the woods; early to mid-summer; 16-777, 29-7-78, 13-7-79, 4-8-80.

PHRODITE FRITILLARY (Speyeria aphrodite) - very abundant in open areas; early to late summer; 16-7-77, 29-7-78, 3-9-78, 20-8-79, 2-9-79, 3-8$80,4-8-80$; Kondla has identlfied the need for research to clarify varlation at the subspecies level in Alberta. ${ }^{13}$

VARIEGATED FRITILLARY (Euptoieta claudia) - one female was found hilltopping on 20-8-79.

\section{Satyridae}

RINGLET (Coenonympha inornata benjamini) - abundant in richer grasslands and low shrub habltats; mid-spring to early summer; $23-5-76$, 30-5-76, 23-5-77, 4-6-77, 23-6-79, 185-80.

RIDING'S SATYR (Neominois ridingsii ridingsii) - rare on grassy slope wlth considerable proportion of bare ground; 13-7-79.

COMMON WOOD NYMPH (Cercyonis pegala ino) - abundant In rlcher grassland and low shrub habitats; early to late summer; $16-7-77,1-8-77$, 29-7-78, 13-7-79, 4-8-80.

VARUNA ARCTIC (Oeneis uhleri varuna) - fairly abundant in grasslands; early to late spring; 30-5-76, 8-5-77, 23-5$77,4-6-77,23-6-79,9-5-80,11-5-80$, 18-5-80.

ALBERTA ARCTIC (Oeneis alberta alberta) - locally abundant in grasslands; early to mld spring; $1-5-77,8-5-77$, 14-5-78, 21-5-78, 13-5-79, 9-5-80, $11-$ 5-80, 18-5-80; emergence varies by 2 to 3 weeks depending on spring weather; in late springs the main fllght period of the Alberta Arctlc overlaps that of the Varuna Arctlc.

RED-DISKED ALPINE (Erebia discoidalis mcdunnoughi) - fairly common but locally distributed In fescue grasslands; early to mld-spring; 1-5$77,14-5-78,11-5-80$.

COMMON ALPINE (Erebia epipsodea) fairly common in richer grasslands and low shrub areas; mld-spring to early summer; 4-6-77, 23-6-79; Ehrlich shows the study area to be In a zone of intergradation between $E$. $\theta$. freemani and $E$. $\theta$. epipsodea. $\mathrm{He}$ also indicates that no abrupt boundaries exist between the subspecles and that considerable varlation withln a population masks geographlc 
variation unless longer series of specimens are available for study. When more material is available this population will likely be assignable to the subspecies freemani.

\section{Dlscussion}

A total of 57 species have been found, 55 of which are probably resident in the study area. The fauna is comprised of: Hesperiidae 13 (23\%), Papilionidae $3(5 \%)$, Pieridae 5 $(8 \%)$, Lycaenidae $12(21 \%)$, Nymphalidae 17 (29\%), Satyridae 7 $(12 \%)$. Except for a substantially enriched Hesperiidae fauna and depauperate Pieridae fauna, this is representative of the situation in Alberta as a whole. As in most prairie areas, the skipper fauna here is rich in comparison to the boreal and cordilleran regions of the province. For a non-cordilleran area, the Speyeria fauna is surprisingly rich, in both number and abundance of species. The violet flora (food plants of the greater fritillaries) is equally rich, including Viola adunca, $V$. nephrophylla, $V$. nuttallii, $V$. pedatifida, $V$. rugulosa.

The Satyridae are predominantly spring fliers here. The few Pieridae of the study area are found throughout the spring and summer. Most of the Lycaenidae, especially the blues, are spring fliers although the hairstreaks are distinctly summer fliers. The Nymphalidae fly most abundantly from late spring to midsummer. Skippers include spring flying species with legumes and poplars for larval food plants, and summer flying species with grasses for larval food plants. Overall abundance and diversity was greatest in the spring in the grassland and in summer in shrubland and woodland habitats.

Butterfly phenology data does not show a pronounced short term peak in species diversity as other areas in
Alberta, i.e. Calgary², Plateau Mtn. Kananaskis Provincial Park ${ }^{14}$, Star dard $^{13}$. In the present study area species diversity rises rapidly $t$ almost maximum by mid spring with poorly defined peak in late spring an then a slight drop followed by hig diversity until midsummer. Only i late summer is there a substantie reduction in species diversity.

According to the account of mat locating behavior given by Scott, th two major methods used to locat mates are: perching behavior (male rest at characteristic sites and in vestigate passing objects by flying ou at them) and patrolling behavio (males fly almost continuously search of females). ${ }^{18}$

Information provided by Scott ${ }^{19}$ an personal observations show that th fauna of the study area is made up c 31 species which predominantly us patrolling behavior and 24 specie which predominantly use perchin behavior to locate mates. Th Hesperiidae are predominantl perchers while the Papilionidae ar inveterate patrollers. Some specie peculiarities that were noted are: th Assiniboia Skipper and Nevad Skipper characteristically perch of hill and ridge tops; the Zelicao Swallowtail and Badlands Old Worl Swallowtail patrol less than 2 metre above the ground on grassy hilltop while the Tiger Swallowtail patrol mostly at heights of 2-5 metres at th edge of aspen forest. The Pieridae ar all patrollers, as are most of th Lycaenidae, although the hairstreak and coppers are perchers.

Most of the Nymphalidae ar patrollers, especially the greate fritillaries which are very active. Th Satyridae are interesting because th early flying species use perching behavior supplemented by patrollin while the later flying species ar patrollers. The visibility of individua butterflies is correlated with the 
nount of time they spend flying. The ct that patrolling males spend more ne flying than do perching males as a definite influence on population timates based on visual estimates flying butterflies.

Since the study area is the highest $I$ in the region with many local, haller scale topographic highs, this scussion would not be complete thout treating the phenomenon of Itopping. In the broadest sense the $\mathrm{m}$ refers to the congregation of incts on various kinds of topographic gh points in the landscape. ${ }^{20}$ The pic has generated substantial disssion and Shields presents a comehensive literature review. ${ }^{21}$

Many explanations or theories have en advanced but it is overly mplistic to suggest a single best exanation for the phenomenon. In the ore narrow, behavioral definition of Itopping ${ }^{17}$ it seems most widely cepted that hilltops are meeting eas for the sexes to mate. In the oader definition there are most likea variety of factors and suitable exanations to suit the variety of ecies, ecological circumstances, d geographic locations involved.

Twelve of the species found in the esent study area were very ticeably restricted to or were more undant on local topographic highs. two cases, the Brown Elfin and mon Blue, the restricted disbution of the larval food plants is parly the causative factor. Such is $t$ the case for the Melissa Blue or e grass feeders (Assiniboia ipper, Nevada Skipper, Alberta ctic). Adults of the Assiniboia ipper are strongly attracted to wers of Blazing Star (Liatris punca) while adults of the Nevada ipper were seen to show a similar raction to flowers of Prairie oundsel (Senecio canus) and a hall yellow mustard. Thus, these incts may be attracted to nectar

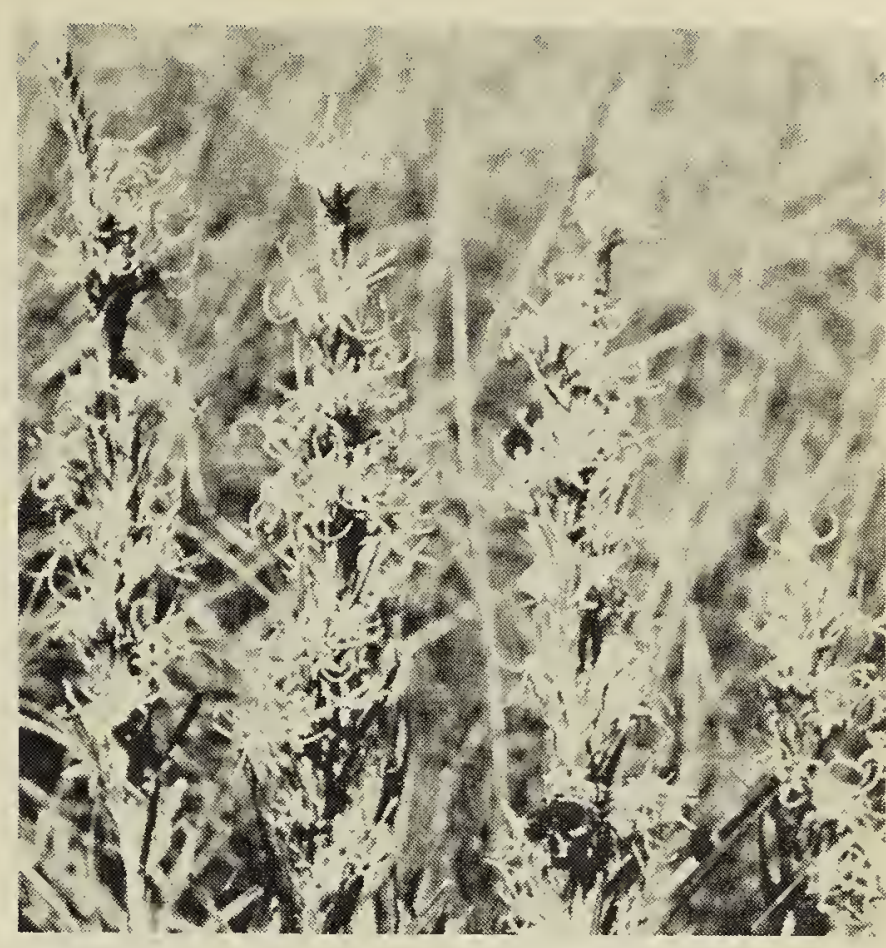

Blazing Star.

Bernard de Vries.

sources abundant on hilltops rather than the hilltop situation.

Alberta Arctic behavior fits the mate-locating definition of hilltopping quite nicely. Males perch on the ridge top, periodically fluttering up several feet, apparently surveying the slope below them for females, and dashing downslope to investigate butterflies at lower elevations. This behavior has been previously described in Oeneis uhleri uhleri in Colorado. ${ }^{15}$

The aggressive, and more or less continuous hilltop flights of the Zelicaon Swallowtail, Badlands Old World Swallowtail, Western Checkered White, Coral Hairstreak, Painted Lady, and Callippe Fritillary are also good examples of matelocating hilltopping behavior.

The study area has a variety of butterfly habitats due to differing slope exposures, groundwater conditions, and grazing history. The grassland and shrubland habitats are much more productive for butterflies than the aspen forest. Naturalists visiting areas like this will find the shrubby edges of aspen forest and grassy hilltops to be superior places 
to observe a variety of butterflies and interesting behavior.

'BIRD, C. D. 1975. A calendar of the butterflles and sklppers of the alpine area of Plateau Mountain. Alberta Naturalist 5:26-28.

${ }^{2}$ BIRD, C. D. 1975. A revlsed calendar of the butterflles and skippers of Calgary. Calgary Field Naturallst 6:312-314.

${ }^{3}$ BIRD, C. D. 1979. The Question Mark another "eastern" butterfly new to Alberta. Alberta Naturallst 9:66.

${ }^{4} B O W M A N$, K. 1944. Additions and corrections to checklist of the macrolepidoptera of Alberta. Canadlan Entomologist 76:191-192.

${ }^{5}$ CASE, J. W. and C. D. BIRD. 1977. Butterflies and skippers of westcentral Alberta. Blue Jay 35:208-219.

${ }^{\circ} \mathrm{CLENCH}, \mathrm{H}$. K. 1972. The boundary between Satyrium liparops and Its subspecies strigosum (Lepldoptera: Lycaenidae). Annals of the Carnegie Museum 44:11-24.

'dos PASSOS, C. F. 1964. A Synonymlc Ilst of the Nearctic Rhopalocera. Lepidopterists' Soclety Memoir 1. 145 pp.

${ }^{8}$ dos PASSOS, C. F. 1968. A name for Polygonia satyrus marsyas (Lepidoptera: Nymphalidea). Transactions of the Amerlcan Entomological Society 95:153-159.

${ }^{\circ}$ EHRLICH, P. R. 1955. The dlstrlbution and subspeciatlon of Erebia epipsodea Butler (Lepidoptera: Satyridae). University of Kansas Science Bulletin 37:175-194.

${ }^{10} \mathrm{FERRIS}, \mathrm{C}$. D. 1973. A revislon of the Colias alexandra complex (Pieridae) aided by ultravlolet reflectance photography with designation of a new subspecies. Journal of the Lepidopterists' Soclety 27:57-73.

${ }^{11}$ FISHER, M. S. 1977. The taxonomy and identity of Papillo nitra W. H. Edwards in Colorado (Papillonldae). Bulletln of the Allyn Museum 47:1-8.
${ }^{12}$ HOOPER, R. R. 1973. The butterflies Saskatchewan. Saskatchewa Museum of Natural History. 216 pp

${ }^{13}$ KONDLA, N. G. 1979. Skippers an butterflies of a prairie farm. Albert Naturalist 9:71-75.

${ }^{14} \mathrm{KONDLA}, \mathrm{N} . \mathrm{G}$. and C. D. BIRD. 1979 The skippers and butterflles Kananaskis Provincial Park, Alberta Blue Jay 37:73-85.

${ }^{15}$ MASTERS, J. H. and J. T. SORENSON 1969. Field observations on fores Oeneis (Satyridae). Journal of th Lepidopterists' Society 23:155-161.

${ }^{18} \mathrm{McDUNNOUGH}, \mathrm{J} . \mathrm{H}$. 1939. A new rac of Papilio belonging to the machaor complex. Canadian Entomologis 71:216-217.

${ }^{17}$ SCOTT, J. A. 1968. Hilltopping as mating mechanism to aid the surviva of low density species. Journal of Research on the Lepidoptera 7:191 204.

${ }^{18}$ SCOTT, J. A. 1974. Mate locating behavior of butterflies. American Midland Naturalist 91:103-117.

${ }^{19}$ SCOTT, J. A. 1975. Mate locating behavior of western North American butterflies. Journal of Research on the Lepidoptera 14:1-40.

20SHEPARD, J. H. 1966. A study of the hilltopping behavior of Pieris occidentalis Reakirt (Lepidoptera: Pieridae). Pan-Pacific Entomologlst 42:287-291.

${ }^{21}$ SHIELDS, O. 1967. Hilltopplng: An ecological study of summit congregation behavior of butterflies on a southern California hill. Journal of Research on the Lepidoptera 6:69178.

22STALKER, A. M. 1973. Surficial Geology of the Drumheller Area, Alberta. Geological Survey of Canada Memoir 370. 122 pp.

${ }^{23}$ TAVERNER, P. A. 1919. The birds of the Red Deer River, Alberta. Auk 36:1-21, 248-265.

${ }^{24}$ THORMIN, T. W. 1977. The butterflles of Beaverhill Lake. Edmonton Naturalist 5:160-163. 